\title{
With Salvage and Knife Tongue Postcommodity ${ }^{1,2}$
}

my

up

side

down

home

faces

east 34

i made it that way 5

when i became its hostage 67

(with salvage

and knife tongue ${ }^{8}$

it reminds people 9

what is possible 1011

if you

work

hard

and abandon reason 1213 
ART IN THE GLOBAL PRESENT

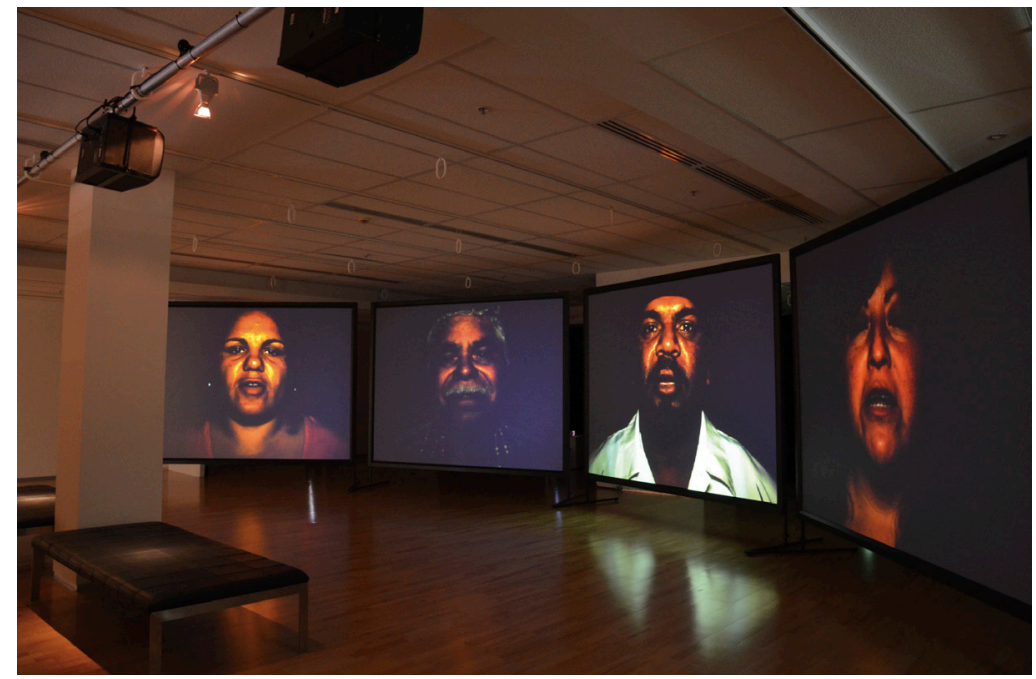

7 Postcommodity

With Salvage and Knife Tongue, 2011-2012 
POSTCOMMODITY: WITH SALVAGE AND KNIFE TONGUE

i often ask my children

to remember

words

attached

to water 14

we once

passed

through 15

the way earth

filters light 1617

and

our

being 1819

the way tools

are used 20

to bend 2122

circum

stance 2324 


\title{
if you ever thought
}

you would hear music ${ }^{25}$

at this point

a drum

a trumpet 26

or some

thing 27

it never happens

in public 28

\author{
night simply \\ appears \\ and falls \\ away
}

the market

closes and opens 2930

a new referendum ${ }^{31}$

becomes

law 32 


\section{Notes}

1 For the Adelaide Festival 2010, the American indigenous art collective Postcommodity developed the work With Salvage and Knife Tongue as a way of exploring the potential commonalities between North American and Australian indigenous peoples in terms of worldview and experiences with colonisation. In particular, the work highlighted indigenous cultural appropriations of English language dialects as tools of self-determination during a time when the world's majority of indigenous languages are disappearing at an unprecedented rate. This phonemic inquiry contributes to a work of art that both linguistically underscores intercultural differences while also making concrete a unifying connection between the Cherokee and Pitjantjatjara - two indigenous groups separated by the Pacific, yet who have both survived British colonisation and removal from their ancestral homelands.

3 With only one of us having visited Australia before, our comprehension of the vastness of the land was severely skewed. We grew up in schools where we were taught to study maps that are flattest when the United States is in the centre, allowing our home country to stretch to its maximum size, relegating other lands to confined corners. Upon our arrival we began, on an experiential level, to grasp the immensity of Australia and, with this humbling sense of place, we began to learn more about the monumental number of indigenous languages, which are spoken by hundreds of Aboriginal groups covering an area larger than Texas twelve times over.

The immersive installation environment features a semicircle of four large video projection screens showcasing computationally generative combinations of four American and/or Australian indigenous people articulating lines of an indigenous empathetic poem-about the displacement of people (which is about getting kicked out of or forcibly removed from your home) resulting from the early twenty-first-century global economic meltdown. These four projections feature varying combinations of actors and lines of poetry emerging into endless patterns of symmetry and asymmetry. (Figure 7) All possible combinations of variables, which include gender, age group, ethnicity and poetic line, are generated using a probability model that changes over time.

5 To achieve this, the piece simultaneously synthesises and contrasts Cherokee and Pitjantjatjara uses of English by visually and sonically underscoring the linguistic phonetic features forming their English language accents.

6 Literacies such as reading, writing and digital media are not going away-it's time to reimagine these literacies through our own worldviews.

7 With Salvage and Knife Tongue demonstrates the indigenous adaptive reuse of the English language as a means of survival in the face of subjugating and historically violent forces.

8 When given only the coloniser's tools, an American Indian might find himself or herself ill-equipped to understand an indigenous people from a polar-opposite land. Making one feel as they know very little when in actuality middlemen can be eliminated.

9 One of the most striking aspects of learning that took place during these dialogues was Postcommodity's realisation that English as a mode of communication was not fluid between itself as a collective and its Australian Aboriginal collaborators. This realisation by Postcommodity was counter to its assumptions of what it would encounter. In other words, the Pitjantjatjara family consisted of people who were native language speakers of their indigenous language, whereas the members of Postcommodity were native language speakers of English. We began to think about how this contrast is influenced by differing timelines associated with colonisation. Through the shared struggle between 
Postcommodity and its Pitjantjatjara collaborators to use English as a common language, the art collective was reminded that American Indigenous peoples have been experiencing and rationalising the violent velocities of colonisation for over five hundred and twenty years. As the collective put America's history in context with the differing colonisation timeline of Australia (over two hundred and forty years in the making), it began to experience many faces of colonisation, not only across cultures, but across time as well.

The following is an example that includes the variable of ethnicity as part of the composition. One of these outcomes includes a scenario where two elder Cherokee men and two younger Pitjantjatjara men each individually and simultaneously articulate a differing line, thus resulting in a cacophony of speech, whereas at other times one might witness a younger Cherokee woman, a younger Pitjantjatjara man, an elder Cherokee man, and an elder Pitjantjatjara woman all articulating a chorus of the same line all at once.

11 As the two groups learned how to communicate more fluidly with each other, Postcommodity became aware of what appeared to be a negation between hemispheres of cultural self-determination. This became apparent as the collective observed that North American indigenous groups exercise notions of sovereignty as its people's languages are disappearing, while at the same time, on a different continent, its Pitjantjatjara collaborators did not understand or exercise ideas of sovereignty, yet their language was spoken strongly across generations.

Postcommodity's intentions for mediating this intercultural, multilinguistic and intergenerational complexity across gender are driven by its trickster ethos, characterised by a likeliness to problematise cultural models about humanity often oversimplified by mass media while made concrete by the status quo.

13 Postcommodity's generative algorithm created for With Salvage and Knife Tongue leads to various line-by-line outcomes that, for example, project a scenario where all the people featured at a given moment may all articulate the same line of the poem, while at other times differing combinations of poetic lines emerge revealing other results. With all possible variables considered, With Salvage and Knife Tongue produces hundreds of outcomes. Mixing the previously mentioned variables leads to patterns such as two young women articulating the same line while two elder women articulate a different line all in simultaneity.

14 There is a clear manipulation of diction, structural grammar, syntax, subject/ object/verb relationships, context, meaning, and historical/political/social/ cultural references dispersed among the broken lines and stanzas. It was challenging conceptually, and challenging to read. Any hack job of the English language renders numerous challenges; one is always readability because the issue of readability is in the mind of the person or people hacking the language. The poem cut the issues by positioning a set of metaphors intrinsic to literal and abstract constructs of indigenous/coloniser power and political structures, as well as contemporary indigenous experience and world view. The poem also ensured Postcommodity's role as collaborators off-camera. In this regard, the words provided the conceptual and aesthetic landscape for our collaboration, as well as the primary mediating force of dialogue and intercultural exchange. In terms of cutting the issues, the poem forced people to consciously, or unconsciously, question their own relationship and awareness of language usage, cultural selfdetermination and sovereignty. The people who were most capable of reciting the poem had the strongest command of English and the greatest capacity to manipulate the language, as well as the meaning being conveyed. In this regard, they had the greatest capacity to utilise English as a weapon, or as a code of cultural self-determination and sovereignty. This points to the fact that their relationship with concepts of cultural self-determination and sovereignty are 
more universally codified and self-aware, rather than more experiential or purely experiential. Inversely, their relationships with the economy and the global market forces of colonisation are more experiential and less consciously aware. The people who read most clearly are most integrated into the economy through formal mechanisms. With this in mind, the folks who had the most difficulty reading the lines of the poem have the least interest in the English language, as a code of self-determination, or in general, for daily usage. Clearly, a few people had very little knowledge of the English language. These people are the least integrated into the economy and global market through formal mechanisms. They exist, in large part, outside the global market. Equally important, their relationship with cultural self-determination and sovereignty is not necessarily codified, but, rather, it is far more experiential and less self-consciously aware. These concepts are hugely important to the success of the piece.

15 This temporal nature of Postcommodity's generative model allows the collective to approximate the work's rhetorical and aesthetic structure as it randomly unfolds over the course of time.

16 It is an idea that provided the opportunity for dialogue between indigenous groups that could only take place between two groups in colocated ceremonial space.

17 Postcommodity positioned its invitation to exhibit at the Adelaide Festival, and the curatorial support of Victoria Lynn, to create a new work largely based upon the collective's assumptions regarding experiences that Native Americans and Australian Aboriginal peoples might have in common with each other. These assumptions were artistically expressed by Postcommodity to create a cross-cultural place for an intercontinental indigenous dialogue. This twenty-first-century intercontinental indigenous gathering resulted in knowledge exchange dialogues between Postcommodity, members of the Cherokee Nation, and family members from a Pitjantjatjara community located not far from Adelaide, Australia.

18 These types of meaning-making dialogues cannot take place within the virtual world of the market's global village.

19 in--jiyanv?i-I put (into a container) something living (living) (remote past) Onita Lynch, Laura Anderson, Bobby Blossom, Igajeli Yonega-Jalagi Didelogwasdodi (English to Cherokee Dictionary) (Onita Lynch, 1996), 188.

20 There may be times when in simultaneity a Pitjantjatjara elder and youth (perhaps differing genders or the same gender) together recite one line, while a Cherokee elder and youth (perhaps differing genders or the same gender) together recite a different line. Another example includes a scenario where differing lines map to Cherokee and Pitjantjatjara elders in contrast to Cherokee and Pitjantjatjara youth. Through Postcommodity's generative computational algorithms, these and all possible patterns eventually emerge over time.

21 In their effort to provoke the systematic complexity of intercultural ceremony, Postcommodity created a generative and immersive computational video installation environment complete with spatially projected audio. With Salvage and Knife Tongue is a generative synthesis of varying Indigenous experiences of colonisation geographically - as northern and southern hemispheres, American and Australian and, sonically, as individuals representing unique cultures, and ethnicities.

22 Postcommodity's intentions for mediating this intercultural, multilinguistic, and intergenerational complexity across gender are driven by its trickster ethos, characterised by a likeliness to problematise cultural models about humanity often oversimplified by mass media while made concrete by the status quo.

23 Despite the discontinuity of language between the two groups, a few days of relationship building eventually led to the development of both parties' ability 
to efficiently adapt by using salvaged pieces and parts of language to render communication fluid and comfortable.

24 Despite the differences between many North American and Australian indigenous peoples thus far highlighted, there are strong similarities. Australian Aboriginal and American indigenous groups were removed from their ancestral geographic ecologies, but continue to live on today. Throughout the history of America and Australia, schooling was used and continues to be used by the coloniser as a way to discipline the American and Australian indigenous peoples to swallow coloniser dreams, such as the American dream, or perhaps an Australian dream if there is such a thing.

25 As choirs of poetic lines are visually and sonically displayed, speech is analysed in real time by applying synthesis and re-synthesis techniques of sound using audio convolution and morphing algorithms. These audio techniques allow the characteristics of speakers' voices to influence each other, yielding the similarities and differences between their vocal expressions, which often result in the creation of new voices of shared experience. These new synthesised voices are projected from the rear of the gallery at the same time that the unaffected voices emanate from the respective video screens that given individuals are projected on at a given moment, so if person B is projected on screen one, then a visitor will hear person B's voice emanating from screen one.

26 Postcommodity's work, With Salvage and Knife Tongue, is a linguistic phonemic examination of how indigenous groups in the United States and Australia have appropriated colonial English as a means of rationalising and representing their respective cultural and political identities within the contexts of colonisation, imperialism, neoliberalism, globalisation, and nation-states.

27 With Salvage and Knife Tongue reveals the following questions by Postcommodity: How are we (indigenous peoples from America and Australia) using the English language to represent our indigenous worldviews? How do we use this language as tool to construct some kind of an existence when our futures are about being in debt or in poverty? How do we use the English language as indigenous peoples to build new intercontinental networks with each other?

28 Aspects of these dialogues focused upon the historical and contemporary impacts of colonisation and globalisation stemming from the experiences of the members of Postcommodity, the Pitjantjatjara family and members of the Cherokee Nation. Through processes of dialogue, Postcommodity assembled an international community of collaborators to create content for their place-based work exhibited in Adelaide. Throughout these intercultural dialogues, Postcommodity learned much about the naivety of its assumptions, as well as aspects of its assumptions that were correct.

29 Today these groups continue to endure the exterior forces of the neoliberal global market with a strong resolve for self-determination.

30 Nowhere did capitalism penetrate more rapidly or dramatically then the Trans-Mississippi West, whose 'vast, trackless spaces' (as Walt Whitman called them) were now absorbed into the expanding economy. At the close of the Civil War, the frontier of settlement did not extend far beyond the Mississippi River. To the west lay millions of acres of fertile and mineral-rich land roamed by immense buffalo herds that provided food, clothing and shelter for a population of perhaps a quarter of a million Indians, many of them eastern tribes forced inland two centuries before from the East Coast, and moved again earlier in the nineteenth century to open the Old Northwest and Southwest to white farmers and planters. Although Indian policy provoked much controversy during the Grant years, nearly all military and civilian officials shared a common assumption: that the federal government should persuade or coerce the Plains Indians to exchange 
their religion, communal form of property and 'nomadic' way of life for Christian worship and settled agriculture on federally supervised reservations. In a word, they would surrender most of their land and cease to be Indians. E. Foner, Reconstruction: America's Unfinished Revolution, 1863-1877 (New York: Harper Collins, 1988), 462.

31 In contrast to the experiences of its Pitjantjatjara collaborators, the members of Postcommodity reflected upon their home while in Adelaide and concluded that because concepts of sovereignty have been acknowledged by indigenous communities throughout North America, these groups have been left with little choice but to engage self-determination through concepts of sovereignty. This understanding raised numerous questions regarding whether or not sovereignty is, in fact, the most appropriate framework for nation building and exerting self-determination.

32 To Postcommodity it was evident that the Pitjantjatjara exercised selfdetermination by doing what they do as a people, by simply being who they are as Pitjantjatjara. At the same time, unlike the Cherokee, the Pitjantjatjara have no federal trust relationship or treaty relationship with the government of Australia, thus making them extremely vulnerable to the whims, desires, and values of the Australian nation and the global economy. North American indigenous experiences suggest that this may only develop toward greater disadvantages for Australian Aboriginal peoples with the passage of time. 